\title{
INTEGRATING CHARACTER EDUCATION AND LOCAL WISDOM IN DEVELOPING ENGLISH TEACHING MATERIAL
}

\author{
Muawwinatul Laili \\ Universitas Nahdlatul Ulama Sidoarjo \\ e-mail: muawwinatullaili@yahoo.com
}

\begin{abstract}
There are many moral degradations has influenced students' character. Character education need to be implemented in students' learning activities. However, some teachers find some difficulties in finding and creating a textbook that includes character education in it. Besides, the role of local wisdom is very important in teaching character education and shaping students' identity. The teachers can promote local wisdom through English teaching materials. Both of character education and local wisdom can be integrated in the teaching materials. This research intends to develop English teaching material needed by eighth graders. The design to develop the teaching material is Research and Development (R \& D). The R\&D method procedure that was conducted by the researcher is adapted from Cunningham's R\&D in Borg and Gall (2003). The development process was done by six steps, they are; reviewing relevant of literature, planning the chapter objectives, developing a preliminary form, field-testing the preliminary form, revising the preliminary form based on the field-test results, and conducting a main field test of the revised form. As the result, the final products that integrated with character education and local wisdom can be the solution to promote the local wisdom and the way to teach character to the students.
\end{abstract}

\section{INTRODUCTION}

The National Education System law of 20/ 2003 article 1 states that among the objectives of national education are "developing student's intelligences, personality, and noble character". This statement means that the aim of the education is not only to make the students comprehend knowledge, but also to build good personality and character. It also implies that there is society-based education which highlights culture as the creation of, by, and for the society itself. The culture includes local wisdom which should be developed by the nation. In fact, there is a gap between the law of national education and the reality in the schools: children have limited or even no character development and have already forgotten local genius as their wealth. Character education has to start early to students especially at school. It cannot be denied that there are schools that still find difficulties to apply the character education for the teachers and students especially in selecting the materials that are appropriate with the students' needs and integrated with character education and local wisdom. It means that nowadays English teachers are expected to develop the English teaching materials integrated with character education and local wisdom.

\section{INTEGRATING CHARACTER EDUCATION AND LOCAL WISDOM IN TEACHING ENGLISH}

Most of the current issues in education are related to the character education. Indonesia government recently decides to apply character education as the important factor that must include in education. In this case, Indonesia government settle on the law number 20/2003 on National Education System article 1 states that among the objectives of national education 
are developing student's intelligences, personality, and noble character. Actually, character education is not a new term in Indonesia because Soekarno says that how important nation and character building' for Indonesia which became independent country on $17^{\text {th }}$ August 1945.

Dealing with the character education, Nucci and Narvaez (2000) says that character is different with behavior control, discipline, etc. It has a larger scope and much more ambitious aims. However, good character and good behavior have similar side. 'Character' is a general term for the individual as a whole. It shows that the term 'character' refers to someone's behavior. As the fact that school as one of the educational institution that has important role in educating character for students. It is also said by Nucci and Narvaez (2008) that for many character educators 'Character education' is dealing with formation and transformation of a person and includes education in schools, families, also in society's social networks.

But, some teachers commonly think that there is a little space in the school curriculum to educate for character education. They say that character education is the responsibility of parents. Actually, there are many approaches to character education in schools as explained by Burrett and Rusnak in Herawati (2013) that there are six key principles for an integrated character education program in order the character education can be effective. First, Character education should be a part of every subject. Second, the school and community are vital partners in the character development of youth. Third, the school has to provide a positive classroom environment that support character education is needed. Fourth, empowered teachers - that are teachers with good attitude and committed to implementing character educa- tion curriculum - are in the best position to achieve character goals. Fifth, character education is being encouraged through administrative policy and practice. Lastly, character education is an action education.

Teaching character education must be started from early age and did in daily activities. There are some moral value that must be integrated in curriculum, they are; peacefulness, tolerance, happiness, responsibility, cooperative, simplicity, honesty, freedom, and unity (Tilman in Herlina, 2012). In addition, Ministry of Education and Culture also launched 20 points of character education that must be underlined in school. They are sincere, honesty, humble, affection, discipline, economize, no surrender, justice, positive thinking, independence, peacefulness, tolerance, emotional control, citizenship, responsibility, creativity, hard-working, and collaboration (Ministry of Education and Culture, 2009). In this case, teachers must apply an effective way to promote character education while teaching especially teaching English in order to empower the students with good characters.

In Indonesia there are many English teachers who still use common English teaching that still forget to insert local wisdom to promote character education in Indonesia. According to Setiyadi (2013) local wisdom was firstly introduced by Quaritch Wales (1948-1949). It is an ability of a certain culture to keep the influence of the foreign culture when they contact each other. The local wisdom can be understood as man's effort in applying his cognition to do something and thinking of a certain object, or event happening in a certain place. Further, wisdom in understood as one's ability in using his thought to act to a certain thing as a result of his judgment to a certain thing, object, or event. He also states that local wisdom is a 
custom or tradition done by a group of people living in certain area. In this case, tradition can be used as a law in a certain community.

In fact, many educational experts agree that local wisdom can support nation's character education development. For example, the chief of institute of culture UMM, Sugiarti (2011) in seminar of character education in UMM explains that local wisdom can be used as the content of character education. In that seminar Suminto (2011) also states that recently teachers are proud of the teaching with westernized style. And the result is local wisdom and Indonesian cultures are forgotten by most students (“Local Wisdom", 2011).

Basically, the teachers can insert character education and local wisdom in teaching English. Sudartini (2012) explains that English language teaching educators are practically required not only to teach the language but also to present the cultural context in which this particular language is used. Teachers also need to promote the local content to the students by inserting the local cultural aspects or local wisdom during their teaching and learning process. Meanwhile, the students are also need to learn about the culture of society in using language besides learn about the language.

The important point is the teachers should take the responsibility in order to insert local wisdom while teaching the students. It must be done in order to conserve what we have. Moreover, the teaching of English by using culture also has some advantages. Herawati (2013) states the use of local culture promotes local biodiversity. Besides, it helps the students to easily practice their English because they know the topic very well. Therefore, it is advised for the teachers to implement cultural-based education in the classroom. The teachers have responsibility to promote the local wisdom in teaching English.

In inserting the local wisdom in English teaching materials, the teacher can use some folk tales which are originally from local areas in Indonesia, some texts about traditional foods, traditional houses, traditional clothes, traditional ceremonies, local plants, etc. These texts should be taught for giving the students knowledge about Indonesian's wealth that can build the students' character. It shows that the integrating of character education and local wisdom in English language teaching can be the forms of selecting materials including the local cultures norms and values and also giving additional explanation on any foreign cultural norms found in the process of teaching and learning process. However, the integrating of character education and local wisdom in English teaching will not be successfully carried out without the supports from all everyone who involved in English language teaching, such as the teachers, parents, stake holders, and the government.

\section{MATERIALS DEVELOPMENT}

Materials have important rule in teaching and learning process especially when the teacher uses many materials in every activity. Kitao (1997) says that material is one of important components in language instruction. Connecting with the materials Allwright in Kitao (1997) argues that materials should teach students to learn and control learning and teaching. In contrast, O'Neill in Kitao (1997) argues that may materials be appropriate for students' need, even if they are not designed especially for them. He emphasizes that materials should help the students in learning and teaching process. In fact, there are many Indonesian English teachers who depend on teaching materials in the 
textbooks. They use the textbook without consider about the appropriateness with the students' need and curriculum. They do not understand what language teaching materials are.

According to Tomlinson (2012) materials for language learning are everything that can be used to facilitate the learning of a language, including course book, videos, graded readers, flash cards, games, websites and mobile phone interactions although most of the literature focuses on printed materials. It means that an English teacher can use possible things that support the learning and teaching process.

In addition, an English teacher should know about the characteristics of materials. Kitao (1997) states the characteristic of materials can be seen from three viewpoints; language, information on culture, and learners' viewpoints. From the language viewpoints English textbooks should have correct, natural, recent, and Standard English. The cultural information included in English textbooks should be correct and recent. It can include visual aids to help students understand cultural information itself. Except those characteristics, the content English textbooks should be useful, meaningful and interesting for students. The materials should be chosen based on the students' need and students' interest in order to motivate them. From the difficulty level, materials should be slightly higher in their level of difficulty than the students' current level of English proficiency. English textbook should have clear instructional procedure and method; it means that the teacher and students are able to understand what is expected in every subject and for each activity in the classroom. Moreover, English textbooks should support the learning and teaching process. It can be shown from the form of vocabulary lists and exercises. In line with the explanation above, some teachers spend their time in finding, selecting, evaluating, adapting, and making materials to use in their teaching. There is no doubt that English teachers can or must develop the English teaching materials which are not appropriate with the characteristics of language teaching materials.

Materials development refers to all processes made use of by practitioners who produce and or use materials for language learning including materials evaluation, their adaption, design, production, exploitation, and research (Tomlinson, 2012). Based on the history of materials development there was little attention in mid-1990s. Tomlinson (2012) explains most of the people did it are practitioner and they did it as a sub-section of methodology, in which materials were usually presented as examples of methods. But now, materials development not only undertaken by practitioners but is also a field of academic study. As a practical activity it involves the production, evaluation and adaptation of materials.

Connecting with the material development, there are many English teachers who still use a textbook that published by the publisher. They do not realize that the textbook is not appropriate to apply in some different classes. Moreover, the materials cannot provide the students with character education and promote local wisdom. To solve this problem, English teachers need to develop their own materials based on the students' need.

In developing English teaching material integrated with character education and local wisdom the teachers can follow the procedure of material development by Cunningham that explained in Borg and Gall (2003) as the followings. 


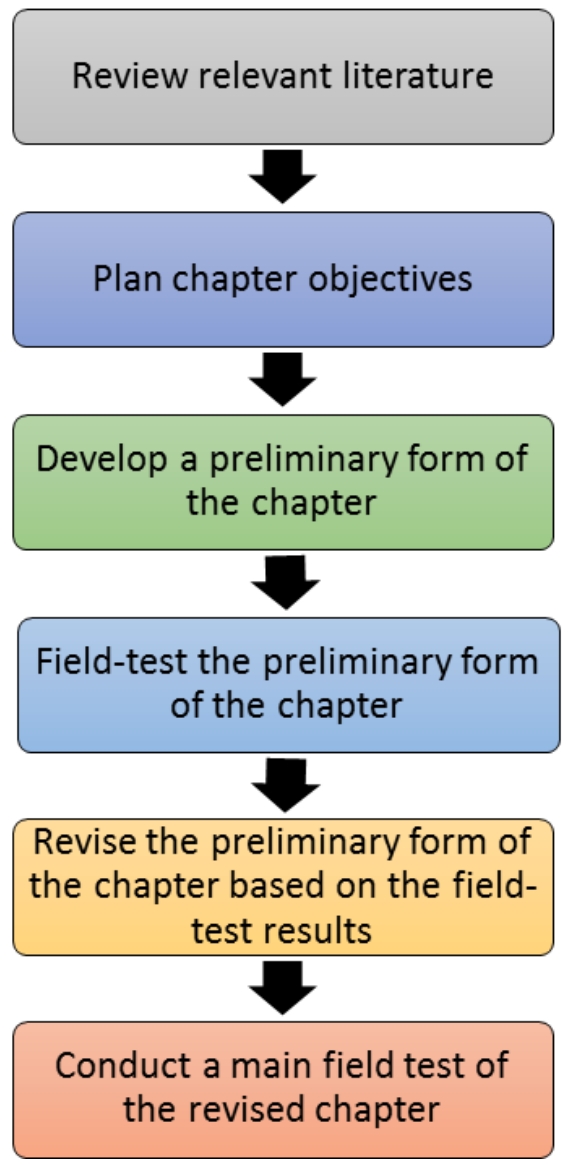

Figure 1: The steps of material development from Cunningham, L. (1987) in Borg and Gall (2003)

The first step is a review the relevant literature that used to collect information about the existing relevant materials, a study of learner characteristics, and a review of the literature on characteristics of effective text. In this step, the teacher can collect much information about the related literature or references dealing with the material developed. According to Latief (2009) the theories, principles, or criteria of effective instructional supporting documents and assessment instruments are reviewed from related references, from teachers' conferences, from discussion with colleagues can be the references to develop material.

The second step in Cunningham's model is planning chapter objectives that focused on identifying objectives for the proposed chapter.
This step also has another purpose. In this step, the researcher selects and identifies some objectives that are appropriate with the materials. The next step is developing a preliminary form of the chapter.

\section{DEVELOPING ENGLISH TEACHING MA- TERIAL BASED ON CHARACTER EDUCA- TION AND LOCAL WISDOM}

This section includes two phases that should be undergone; they are planning the chapter objectives and developing a preliminary form.

\section{A. Planning the chapter objectives}

The objectives were developed for each unit of the text book. The development of the structure of the materials was graded to help the students comprehending the material. The grading of the materials included providing schema building at the beginning of the unit in order to introduce the students what are they going to learn. Based on the objectives of each unit, the researcher decided that the activities would be held in each unit easily. In all elements (observing, questioning, exploring, associating, communicating and reflecting) there are some important information related to the objectives in each unit. This part was called by 'You should know' which also include grammatical information, vocabulary list, generic structure of texts, function of some functional texts, et cetera. It will provide the students with important information during the learning activity.

\section{B. Developing Preliminary Form}

After planning the objectives of each unit, the researcher developed the preliminary form 
of the product which includes the structuring the materials, designing the product, selecting the picture illustration and lay out, deciding kind of font used and its size, also editing the colour of each unit.

In the beginning of each unit there was a title of each unit and under the title there were some basic competencies or KD of each unit. After the basic competence or KD the next part was the learning objectives of the unit. This part will make the students easily to understand what they are going to be learned in each unit. In structuring materials the researcher integrate the four English skills in each activity. Each unit begins with observing activity and followed by questioning, exploring, associating, and communicating activity. Each activity consists of Listening, speaking, reading, and writing skills which were integrated in all activities. The next part of each unit was some important information which provided the students with some explanations and examples of the topic in each unit. The example explained about the expressions in giving attention and how to respond the expressions. Dealing with this part, the students also understand what the important information is that they need to reach the basic competencies of each unit.

There are five units that developed by the researcher and four of them include songs in the listening activity. All of the songs are recorded in a CD that can be played easily by the teacher. Associating activity was provided after Exploring activity which used to make the students associate their knowledge they got by applied their knowledge in their daily activities. The example of detail associating activity were Practice some expressions, Play role in some situations, et cetera.

Continuing the associating activity there was a communicating activity which is aimed to provide the students communication skill in order to practice their knowledge and create some works. The next activity was called by 'Reflection' which is provided with some list of learning objectives that the students learned. In this section the students would understand their ability in comprehending the material. They also knew about their understanding level of material, for example they were good in 'Showing attention' but they need to improve in 'Asking for attention'.

In the end of each unit there is a list of the characters that are learned by the students during the learning activity. The purpose of this part was to provide the students by character education which can support their good attitude in their daily life. The characters that are included were based on the 20 points of character education launched by Ministry of Education and Culture (2009) they are; sincere, honesty, humble, affection, discipline, economical, no surrender, justice, positive thinking, independence, peacefulness, tolerance, emotional control, citizenship, responsibility, creativity, hard-working, and collaboration.

The most important point besides providing the character education is inserting the local wisdom in the texts, dialogues, pictures, and learning activities of each unit. Through this point, the researcher can introduce and promote local wisdom to the students. In addition, Sugiarti (2011) in seminar of character education in UMM states that local wisdom can be used as the content of character education. The result of developing preliminary form will be validated by some experts in the next step and it will be implemented in the class. This preliminary form is the first result of the material development that is never revised before. 


\section{Field-test the preliminary form of the chap- ter}

This process included the try-out of developed material. In this process there were two main English teachers which were chosen as the experts to give such suggestions and review the material. Besides, two English lecturers who were expert in character education and local wisdom were also chosen as the expert validator. This step would produce the first draft. This stage included two kinds of validation processes; they were a teacher validation and an expert validation. In this stage, both the experts and the teachers gave some positive responses about the final products.

In addition, the second expert concluded that the first draft had good content and all of the contents were authentic. The integration between character education and local wisdom were shown in each unit. Besides, each English skill in the each instruction of learning activity was very clear. It can support the students' character in teaching and learning process. But, the flaw of the first draft was the design of the product. According to the second expert, the first draft needed a better design and the size of font must be in the same size and color. The next suggestion focused on the beginning activity of each unit must be similar activities, for example each unit begins with listening activity.

\section{Revision of Field-test Preliminary Form}

Based on the result of field-test preliminary form, there were some points that had to be revised, they were: font size, picture illustration, colour of character list, the sequence of activity, exercises dealing the songs, the sequence of dialogues given, pictures' size, and pictures' illustration. Based on the experts' sug- gestions, the researcher did the revision and the result was the second draft which is directly implemented in a small scale field-test.

The small scale field-test was conducted on $5^{\text {th }}$ January 2015 and there were six students were included as the participants. According to Borg \& Gall (1983:775) small scale field-tests could be included by $6-12$ students in 1-3 schools. The process of the small scale fieldtest was described as follow. The first revision was done to revise the materials that are considered to be inappropriate or ineffective in order to get a more qualified product.

The main field-test was conducted after the draft 1 was revised by the researcher. This step was held on $7^{\text {th }}$ January 2015 and the students' number that included as the participants were 36 students of eight grade. The learning process of the main field-test was similar with the learning process of first implementation. After being revised, the product (draft 2 ), then, was implemented again to the classroom. The second revision was done to revise the Draft 2 in order to produce the better and qualified material. This revision was done based on the result of observation on the implementation 2 and on the result of the questionnaire from the students and the teachers. The number of questions in the questionnaire of the main field-test were the same as the number of questions in the students' questionnaire in the small scale field-test.

The results of the questionnaire showed that there were twenty nine students (80\%) agreed that the textbook's cover was excellent. In the second question there were eighteen students $(50 \%)$ agreed that the pictures illustration were excellent. Then, all of the students $(100 \%)$ stated that the font size was clear and there were twenty nine students (80\%) also 
stated that the whole of textbook's appearance was excellent. These results indicated that the students' opinion about the design of the product was excellent and positive.

Dealing with the students' opinions about the applicability of the product there were four questions that investigated that point. The result showed that there were twenty seven (75\%) students were agreed that the delivery process of the material was excellent and there were twenty nine students (80\%) stated that learning process was worked well when used the product. Moreover, there were twenty nine students $(80 \%)$ agreed that the instructions given in the product were clear and there were twenty seven students (75\%) stated that all activities in the product were easy to be implemented in the classroom. It was clear that there was an increasing of the students' number who stated that the product was applicable.

The last but not the least, related to the product was the difficulty level of the product. The result of the students' opinions about the difficult level of each unit showed that there were thirty three students (92\%) agreed that the difficulty level of each unit was medium level. In this condition, the students could do some activities well and some of them would be excited in doing the activities. The result of the students' opinions about the understanding level of each reading text showed that there were twenty nine students $(80 \%)$ stated that the understanding level of each reading text was medium level. Furthermore, there were twenty seven students (75\%) stated that the difficulty level of instructions' applicability was low. It indicated that most of them could apply the instructions well. The result of the students' opinions about the difficulty level of the product in general showed that there were twenty seven students $(75 \%)$ agreed that the difficulty level of the product in general was medium level. The result above showed that most of the students could do the instructions and activities in the product well.

\section{DISCUSSION AND RESULT}

Based on the results and findings of the research, it can be seen that in development process the researcher had followed the sequence of Cunningham's model in Borg and Gall (2003), material development which started by review of relevant literature to get many references related to the developed material which consist of text books, videos, pictures, MP3 and others. The researcher selected the appropriate references to provide the developed material with the character education and local wisdom and gathered the teachers' problem dealing with the material used in the school.

In developing material process, the researcher also tried to insert character education and local wisdom in some reading texts, songs, dialogues, exercises, and pictures. But there were some difficulties faced by the researcher. The first difficulty faced by the researcher was how to find the appropriate pictures related to each topic of the textbook. Actually, the researcher tried to find a picture illustrator to solve this problem. Finally, the researcher found a picture illustrator in Solo. In this case, the researcher explained what kind of pictures that are appropriate with the topics of the textbook. After that, the picture illustrator draw the pictures and the result will be consulted to the researcher in finding the better pictures. The drawing process of the pictures took for about five months and it also spent much cost. This condition is in line with what has been ex- 
plained by Borg and Gall (2003), that Research and Development will take a long time and much money. The second problem in developing the material was find the songs related to the topics of the textbook. In this case, the researcher tried to download the songs for many times and fortunately all of the songs have been downloaded successfully.

In applying the product in the classroom, the researcher tried to integrate the three language skills, namely; listening, speaking, reading, and writing as suggested by Hinkel (2006), that teaching integrated skills play a central role in promoting communicative language use. This way can build a communicative relation between teacher and students during the teaching and learning process. In this case, the teacher should begin the listening activity and continue with the speaking activity. The next activity was reading and writing activity included some exercises. As the result, the students can relate each skill in learning English.

According to the students' expressions, it shows that the material can be related to the students' experiences. It is in line with what explained by Tomlinson (2012), that there are five types of materials, they are: informative materials means that materials should inform the learners about the target language. The second is instructional materials which can guide the learners in practicing the language. The next is experiential materials that provide the learners with experience of the language in use. Then, eliciting materials are materials that encourage the learners to use the language. The last is exploratory materials which can help the learners to make discoveries about the language.

The goal of implementing the developed material for eighth graders is to promote the local wisdom within students' English learning and educate the students about the character. After implementing the developed material, the result shows that students are stimulated to explore the local wisdom. In short, the goal of developing English teaching material to eighth graders are reached by the researcher. There is an appropriateness between the goal of the research that is developing English teaching material and the students' needs.

\section{REFERENCES}

Borg, W.R. \& Gall, M.D. 1983. Educational Research, An Introduction (fourth edition). New York: Longman.

Draft of 2013 Curriculum. 2013. Ministry of Education and Culture.

Gall, D.G., Gall, J.P., Borg, W.R. 2003. Educational Research: An Introduction (7th ed.). USA: Pearson Education, Inc.

Habeahan, Piator. 2012. Teacher's Instructional Materials in Teaching Reading Comprehension. An article published in STKIP Santa Maria Sibolga.

Herawati, Y.W. 2013. Integrating Character Education and Local Genius through Balabolka in Teaching Listening. A Paper presented at NELTAL. Malang: Faculty of Letters, State University of Malang.

Hinkel, Eli. 2006. Current Perspectives on Teaching the Four Skills. An article published on Tesol Quarterly Vol 40, No. 1, March 2006.

Kitao. 1997. Selecting and Developing Teaching/Learning Materials. An article published on Internet TESL Journal, September 2012.

Krashen, S.D., and Terrel, T.D. 1995. The Natural Approach: Language Acquisition in the 
Classroom. London: Prentice Hall Macmillan.

Law Number 20/2003 on the National Education System in Indonesia.

Lestari, L.A. 2011. The Interactional Approach to the Teaching of Writing 2and Its Contribution to Character Building Education. Surabaya: UNESA Press.

Local Wisdom Supports Character Education. 2011. UMM News. May 1:2

Nucci, L.P. \& Naevaez, D. 2008. Handbook of Moral and Character Education. New York: Routledge.

Oura, G.K. n.d. Authentic Task+Based Materials: Bringing the Real World into the Classroom. Retrieved May 05, 2013. From www.jrc.sophia/ac.jp/kiyou/k121/gaio.pdf.

Rukmini, 2012. Pembelajaran Bahasa Inggris bisa Disisipi Kearifan Lokal. Retrieved September 30, 2013, from www.antaranews. com/berita/300109/pembelajaran-inggrisbisa-disisipi-kearifan-lokal.

Sibarani. 2013. The Character Building based on Local Wisdom. Retrieved September
30, 2013, from www.museum.pusaka-niasorg/2013/02/pembentukan-karakter-berbasis-kearifan.html.

Subekti. 2014. Developing Task-based Material for English Conversation Program at Grade Eleven SMAN Plandaan Jombang. Unpublished Thesis. Surabaya: Pascasarjana Universitas Negeri Surabaya.

Sudartini, Siti. 2012. Inserting Local Culture in English Language Teaching to Promote Character Education. An Article published on Jurnal Pendidikan Karakter. UNY. Edisi Tahun II, No. 1. Page 45-54.

Suyanto. 2013. Urgensi Pendidikan Karakter. Retrieved September, 09, from 40301062. siap-sekolah.com/2013/09/02/urgensi-pendidikan-karakter.

Tomlinson. 2012. Materials Development for Language Learning and Teaching. Cambridge Journal 45.2, 143-179.

Wallace, T., Stariha, W.E., Walberg. H.J. 2004. Teaching Speaking, Listening, and Writing. Brussel: IBE. 